Mao's People 



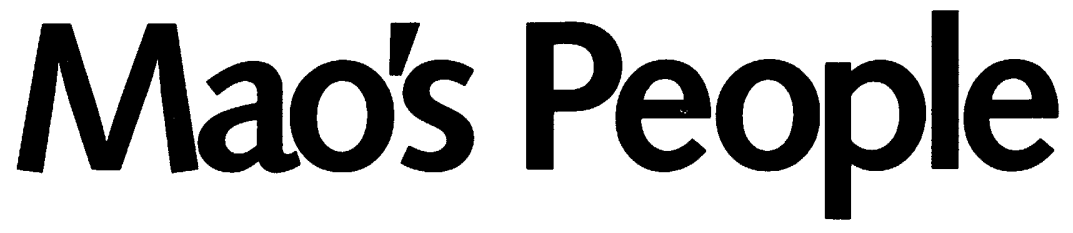

Sixteen Portraits of Life in Revolutionary China

\section{B.Michael Frolic}

Harvard University Press

Cambridge, Massachusetts

London, England 
Copyright (C) 1980 by the President and Fellows of Harvard College

All rights reserved

Printed in the United States of America

Library of Congress Cataloging in Publication Data

Frolic, B Michael, 1937-

Mao's people.

1. China-Social conditions - 1949-1976-Case studies. 2. Chinese in Hongkong - Interviews.

I. Title.

HN737.F76

$309.1^{\prime} 51^{\prime} 05$

79-23013

ISBN 0-674-54846-9 (cloth)

ISBN 0-674-54845-0 (paper)

Designed by Mike Fender 
For My Family 
